Khodachuk Yana, Maslova Yuliia. Gender stereotypes in the information picture of the world (on the example of Ukraine and Poland). Journal of Education, Health and Sport. 2021;11(6):28-36. eISSN 2391-8306. DOI http://dx.doi.org/10.12775/JEHS.2021.11.06.003

https://apcz.umk.pl/czasopisma/index.php/JEHS/article/view/JEHS.2021.11.06.003

https://zenodo.org/record/4904749

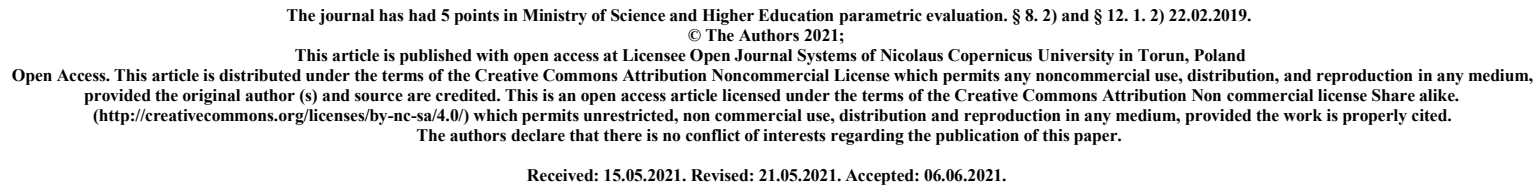

\title{
Gender stereotypes in the information picture of the world (on the example of Ukraine and Poland)
}

\section{Yana Khodachuk, Yuliia Maslova}

National University of Ostroh Academy, Ostroh, Ukraine

\section{Anotation}

The article defines the concept of "gender". Women's gender stereotypes in the Ukrainian and Polish media environments are analyzed. Based on the obtained results, comparisons were made and conclusions were made.

Key words: gender; stereotype; stereotyping; gender stamps; information; mass media.

UDC 305::316.647.82

Ходачук Яна, Маслова Юлія

Khodachuk Yana, Maslova Yuliia

Національний університет «Острозька академія»

\section{ГЕНДЕРНІ СТЕРЕОТИПИ В ІНФОРМАЦІЙНІЙ КАРТИНІ СВІТУ (НА ПРИКЛАДІ УКРАЇНИ ТА ПОЛЬЩІ )}


У статті визначено поняття гендер. Проаналізовано жіночі гендерні стереотипи в українському та польському медіа-середовищах. Описано моделі гендерної ідентичності жінки крізь призму стереотипізації. На основі отриманих результатів здійснено порівняння та зроблено висновки.

Ключові слова: гендер; стереотип; стереотипізація; гендерні штампи; інформація; мас-медіа.

Постановка проблеми. Становлення етичних i моральних ідеалів та трансформація традиційних цінностей в суспільстві здебільшого відбувається завдяки впровадженню нових інформаційних і комунікаційних технологій в медійному середовищі країни. На сьогодні поняття «гендер» відіграє важливу роль у житті кожної людини, адже зміни в суспільстві впливають на гендерні погляди, зокрема на уявлення про жіночність і роль жінки та іiі становище в сучасному світі. Стає все більш помітне перетворення жіночого традиційного образу у сучасних мас-медіа України та Польщі.

Українські медіа продовжують демонструвати здебільшого жінку, як берегиню домашнього вогнища та добробуту. Важливе місце посідає модель Жінки-Матері, адже саме вона вплинула на формування особливих традиційних цінностей в українців та вклала важливий внесок в формування національної свідомості. 3 розвитком медійних технологій з'являлися нові моделі гендерної ідентичності жінки, такі як: Барбі, Жертва. Справжньою рідкістю є подання образу жінки у засобах масової інформації (далі - ЗМІ) у більш прогресивних напрямках, таких як: Жінка-Бізнесвумен, Жінка-Політикиня, Жінка-Науковиця та інші.

Що стосується польських медіа, то на просторах засобів масової інформації поширені стереотипні жіночі ролі такі як: матір, дружина, школярка, студентка. 3 модернізацією у сфері мас-медіа 3'являються нові моделі гендерної ідентичності жінки такі як сильна, незалежна жінка.

Аналіз останніх досліджень і публікацій. Серед науковців, які активно досліджували та досліджують проблему гендерної ідентичності жінки, слід виокремити Кісь О. Р., Маслову Ю. П., Ковальову Г. П., Даніл'ян В. О., Колпак Т. В, Мельникову О. Т, Кірчеву Н. С.,Срмолаєву Т. В., S. Królikowska, A. BalczyńskaKosman, I. Desperak. 


\section{Завданнями даної статті:}

- Визначити поняття «гендерний стереотип»;

- Проаналізувати жіночі гендерні стереотипи в українському медійному середовищі;

- Проаналізувати жіночі гендерні стереотипи в польському медійному середовищі;

- Порівняти отримані результати та зробити висновки.

Метою статті є аналіз жіночих гендерних стереотипів, які використовуються в українських та польських мас-медіа та їхнє порівняння.

Викладення основного матеріалу дослідження. Упродовж історії людства завжди виникали певні уявлення про жінок та чоловіків. Тривала боротьба між статями за владні ресурси триває й дотепер, однак часто видозмінюється, оскільки на формування гендерних стереотипів впливають такі чинники, як: соціальні, економічні, демографічні, воєнні, психологічні, емоційні, культурні, релігійні, національні та інші. Саме завдяки їм формуються уявлення про те, якими повинна бути жінка та чоловік, та які соціальні ролі та поведінка притаманні кожному 3 них завдяки інформаційному впливу.

Більшість дослідників гендерних питань погоджуються 3 думкою, що гендерний стереотип - це узагальненні уявлення про чоловіків та жінок, які сформувались за допомогою розвитку культури. Виявляються насамперед як гендерно-рольові стереотипи, що стосуються прийнятності різноманітних ролей i видів діяльності для чоловіків і жінок, а також як стереотипи гендерних рис, тобто психологічних та поведінкових характеристик, притаманних чоловікам і жінкам. [1]

У теорії токенізму Розабет Кантер дослідила чотири стереотипні образи, які нав'язують жінкам:

1. «Мати» - це та, яка завжди прийде на допомогу, підтримає та створить сімейну атмосферу, а не проявлятиме черствість.

2. «Спокусниця» - жінка, що виступає в ролі сексуального об’єкта для чоловіків, а як ділова жінка ігнорується ними.

3. «Талісман» - та, хто приносить удачу чоловікові та не більше. Ні в якому разі не буде сприйматися як любляча жінка чи діловий партнер.

4. «Залізна леді» - жінка, якій приписують жорстокість, сталеві почуття та ізольованість від соціальних груп.

Проаналізувавши наукові роботи дослідників, які виокремлюють класифікацію моделей гендерної ідентичності жінки, можна виокремити шість основних моделей, які домінують в інформаційній картині світу. Серед них: Берегиня, Барбі, Сексуальна іграшка, Феміністка та Ділова Жінка. 32004 року спостерігається процес переорієнтації гендерних характеристик. До прикладу, лідерські якості в суспільстві перебирає на себе жінка та часто визнається 
чоловіча слабкість. Жінки в сучасному суспільстві прагнуть до андрогінії. Вони намагаються гармонійно поєднати в собі фемінні та маскулінні риси, тоді як для чоловіків характерне більш звичне та бажане бачення в жінці переважно фемінних якостей. [2]

Не зважаючи на традиційність та автентичність, образ Берегині є сучасним. Він прийшов на зміну «радянській супер жінці» після часів Перестрою. Адже суспільству потрібно було створити модель ідеальної жінки 3 національними характеристиками. Українська дослідниця Оксана Кісь стверджує, що стереотип Берегині виявляється у багатьох образах - символ жінки-матріарха. [3] До образа Берегині відносять образ матері, хоронительку домашнього затишку, захисницю дітей та чоловіка. Саме жінці-Берегині присвячені цілі рубрики провінційних газет та глянцевих журналів, що задають моделі поведінки, поради з догляду за дітьми, створення домашнього затишку тощо. [4] Мешканці України разом зі населенням Східної Свропи за ставленням до дітей як засобу соціальної реалізації жінок якнайбільше наближені до оцінок західних африканців. 70\% наших співгромадян вважають, що само реалізована жінка обов'язково повинна мати дітей. Таку думку підтримують і жінки, і чоловіки однаково. У суспільстві біологічна здатність вважається соціальним призначенням і шляхом соціальної самореалізації, що може означати усвідомлення й прийняття практичної недоступності інших наявних у суспільстві шляхів втілення закладеного в кожній людині, незалежно від статі, людського потенціалу. [8]

Ще одним популярним стереотипом є модель Барбі. Сучасна Жінка-Барбі - це висока, худорлява білявка, яку цікавить лише мода та ії зовнішній вигляд. Згідно iз характеристикою даного стереотипу такі жінки не проявляють свої інтелектуальні здібності належним чином. До прикладу, на каналі ICTV у передачі «Dizel show» часто використовують у сценках образ Барбі для його висміювання: «Блондинка на заправці: як довести водіїв до шаленості» (2015), «Блондинка розбила машину чоловіка» (2017), «Як блондинка купила всім подарунки на Новий Рік» (2016) та інші. Призначення такої жінки - це вдале заміжжя і гламурне життя, постійний догляд за собою та публічність у соціальних мережах.

Ділова Жінка - це стереотип, який трансформувався та ввібрав в себе якості 3 Берегині та Барбі, адже ЗМІ демонструють, що така жінка $є$ красивою, розумною, успішною та наділена властивостями Берегині.

Ще одна популярна модель гендерної ідентичності жінки - це Жінка-Жертва. Ця модель демонструє жінку, як нещасну, незахищену плакальницю у якої в житті все погано. Нерідко, дану модель застосовується у соціальних рекламах та відеороликах. До прикладу, «Арабським жінкам найважче у Єгипті дослідження» (BBC News Україна. - 2013. - 12 листопада) та соціальна реклама від Фонду Олени Пінчук «АнтиСНІД» (Serery. - 201.7 - 2 березня). 
У сучасних медіа все частіше 3'являється специфічний образ жінки Сексуальна іграшка. Візуальний образ жінки все більше піддається «сексуалізації», а в певних випадках і «порнофікації». Такі результати оголосили вчені-соціологи з Університету Баффало.

В українських 3МІ часто застосовують такі стереотипні образи у статтях, на телебаченні та просто в розважальних програмах. Тому постає питання «А навіщо це відбувається? Чому потрібно вводити в оману суспільство, подаючи примітивні моделі жінок?» Тому можна висунути гіпотезу, що ЗМК нівелюють образи Жінки-Бізнесвумен, Жінки-Науковиці, Жінки-Політикині, Жінки-Лідерки та Ділової жінки, оскільки найчастіше власниками медіа являються чоловіки і їм не вигідно просувати у маси не стереотипні моделі ідентичності жінки. На приклад, всі популярні телеканали знаходяться під керівництвом чоловіків: ICTV, Новий канал, СТБ, M1 та M2 належать Віктору Пінчуку, $1+1$ - Ігорю Коломойському, телеканал «Україна» - Рінату Ахметову, а 5 канал та Прямий належать Петру Порошенку. Проаналізувавши дані канали та їхні телепередачі, які популярні, хочеться зауважити, що нечасто демонструють модерні образи жінок. Зазвичай, модель жінки подають через Берегиню, Феміністку та Барбі. До прикладу, на телеканалі «Новий канал» здебільшого розважальний контент. У таких програмах як «Топ-модель по-українськи», «Хто зверху?», «Хто проти блондинок?», «Від пацанки до панянки» завжди нівелюють образи жінок та стараються звести їх до стереотипних. Демонструючи надмірну жорстокість, недотепність, надто відверту поведінку, розкутість та русифікацію.

Що стосується телеканалів 3 політичним спрямуванням, то спостерігається певний прогрес. У програмі «5 каналу» є передачі «Вечір 3 Яніною Соколовою» та «Час. Підсумки тижня 3 Анною Мірошніченко», які показують, що жінки можуть бути експертами у політиці та соціальних науках. Хотілося б зауважити, що часто провідними експертами у політичні програми запрошують чоловіків, водночас жінки знаходяться у ролі провідних ведучих.

У польських ЗМІ схожа ситуація, адже раніше у жінок були лише чітко відведені образи, які транслювалися у медіа.

У рамках дослідження, яке проводив Instytut Stosunków Międzynarodowych (2014) на основі 13 поглиблених інтерв'ю $з$ журналістами та видавцями, які працюють у таких 3MI: TVP, Polsat, TVN, TV Biznes, було виявлено, що самі ж працівники підтверджують стереотип, що певні галузі «належать» лише чоловікам і в цей же час, вони не докладають ніяких зусиль, щоб знайти ЖінкуЕкспертку 3 даної галузі. Але результати опитування продемонстрували, що Жінки-Експертки приходять на ефіри краще підготовлені, прагнуть до консенсусу, більш аналітичні, зосереджені на деталізованій розмові та являються більш практичними у своїх поглядах. Чоловіки ж, як правило, більш зосереджені на конкуренції та суперечках демонструючи свої погляди та аргументи на дану ситуацію. [6] 
Жінок частіше демонструють в ЗМІ як матерів, дружин, студенток, ділових жінок. Їх наділяють наступними ролями: патріотична жінка, скромна жінка, віддана своій родині жінка та жінка, що живе в тіні чоловіка.

Magdalena Grabovska у своїй статті стверджує, що жінки негативно ставляться до реклами, які демонструють жінок у ролі предметів сексуального характеру та вважають це надто принизливим. Також вони критично відносяться до реклами в якій жінок зображують як людей, які не можуть приймати найпростіші рішення без допомоги чоловіків. Вони рішуче відкидають стереотип беззахисної жінки, яка звертається до чоловіка за допомогою та знаходиться завжди у його тіні. На такі твердження вкрай бурхливо відреагували домогосподарки, вони вкрай негативно оцінили їх. [9]

У нещодавно дуже популярних серіалах та мильних операх, які, однак, не є інформативними (хоча i впливають на думки), можна помітити, що жінки реалізовуються у різних професіях та мають різні економічні та матеріальні статуси. Однак для більшості 3 них головним значенням завжди є сім'я та дім, а найбільше - діти (Twardowska, Olczyk 2003).

Ще одним яскравим прикладом $є$ «Bluszcz». Проаналізувавши його крізь роки хочеться зауважити, що крім практичних порад по веденню домогосподарства, підіймалися питання працевлаштування та освіти жінок. Журналісти, що писали статті у даному журналі виступали за права жінок, але в той самий час охороняли традиційні жіночі цінності та ролі. Даний журнал зіграв важливу роль, оскільки пробудив обізнаність у польських жінках та став живильним середовищем у якому могли б проростати дуже радикальні ідеї.

Наразі найпопулярнішими журналами у Польщі для жінок $є$ Cosmopolitan, ELLE, Vogue Polska, Glamour та Рani. Їхній контент стає все більш різноманітний, адже з'являються заголовки, яких раніше не було. До прикладу, «Сzy mężczyźni boją się silnych kobiet (Cosmopolitan, 2019), «Jak mieć czas na wszystko?» (Cosmopolitan, 2019), «Siła kobiet» (ELLE, 2020), «Ciało w dobrej kondycji» (ELLE, 2020). 3'являється нова модель гендерної ідентичності жінки і це сильна жінка. Жінка, яка працює на роботі; жінка-керівник; успішна жінка; спортивна жінка; жінка, яка насолоджується життям; жінка, яка самовдосконалюється та розвивається у всіх життєвих напрямах.

Такі зміни у ЗМІ з'явилися після прийняття Політики гендерної рівності у медіа у 2011 році, згідно із якою потрібно висвітлювати новини, не враховуючи

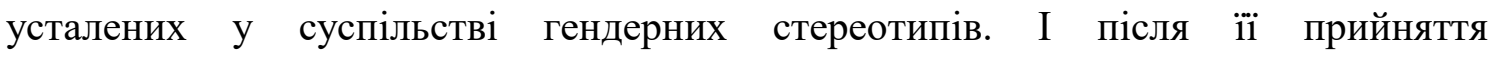
спостерігається зміна ролі жінки у журналах, статтях. Жінок запрошують як провідних експертів з різноманітних галузей, про них пишуть як про сильних та успішних.

Звісно ж, стереотипні моделі поведінки жінки нікуди не зникли. I на сьогодні в заголовках все ще трапляються поради по догляду за будинком, поради у сфері стосунків, поради зі сфери краси, а також поради зі сфери моди. На приклад, 
«Moda dla zabawy» (ELLE, 2021), «Idealne włosy. 5 najmodniejsze fryzury sezonu» (Cosmopolitan, 2019), «Rozmawiamy o seksie» (Glamour, 2021).

Висновок. Отже, гендер як соціальний феномен дає уявлення про дійсність міжстатевих стосунків, які виражаються у міжособистісних соціально-правових, економічних та політичних відносинах. На сьогодні основним об'єктом гендерних досліджень $\epsilon$ жінка, соціальні відносини між жінками та чоловіками та сприйняття жінок чоловіками. А гендерну ідентичність жінки науковці визначають як усвідомлення нею себе, як представницю статті, гендеру, жіночності, відчуття свого тіла та усвідомлення своєї приналежності до статті в соціальному контексті. Визначено, що основною складовою створення моделі гендерної ідентичності є стереотипи, за допомогою яких визначається до якої моделі потрібно віднести ту чи ту жінку. В інформаційній картині світу гендерні стереотипи стосовно жінки набули та набувають популярності. В українських медіа виокремлюють безліч гендерних моделей та найбільш популярними є: Берегиня, Барбі, Ділова Жінка, Сексуальна іграшка, Феміністка та Жінка-Жертва. Разом $з$ цим помітними стають моделі Жінки-Бізнесвумен, Жінки-Науковиці, Жінки-Політикині, Жінки-Лідерки та Жінки-Експертки, які використовують у телепередачах, на сторінках журналів та в онлайн статтях.

Такими на початок 21 століття маємо уявлення про гендерні ролі в українському суспільстві, що $є$ одним 3 проявів соціально сконструйованих суспільних установок. Звісно ж питання гендеру неодмінно розвиватиметься. Рано чи пізно громадським організаціям, органам державної влади та політичним партіям доведеться продумати та вибрати правильну стратегію гендерного паритету, щоб завоювати довіру громадян.

У Польщі ситуація схожа з Україною. У ЗМІ часто використовували стандартні та стереотипні образи жінок (мати, студентка, школярка, ділова жінка i т. д.). Лише з трансформацією цінностей суспільства відбулися певні зміни. Жінок почали сприймати на рівних разом з чоловіками. Відтепер лідирує образ успішної та сильної жінки, яка здатна на все та виступає експертом у різноманітних сферах.

\section{Список використаних джерел та літератури}

1. Оксамитна С. Гендерні ролі та стереотипи [Електронний ресурс] / С. Оксамитна. 2004. - Режим доступу до ресурсу: http://ekmair.ukma.edu.ua/bitstream/handle/123456789/4808/Oksamytna_Henderni_roli.pdf.

2. Галустян Ю. М. Деякі аспекти гендерної ідентифікації та соціалізації особистості [Електронний ресурс] / Ю. М. Галустян, В. П. Новицька. - 2004. - Режим доступу до ресурсу: https://ukr-socium.org.ua/wp-content/uploads/2004/01/7-13_no1_vol-3_2004_UKR.pdf.

3. Кісь О. Моделі конструювання гендерної ідентичності жінки в сучасній Україні / О. Кісь // Ï. - 2003. - № 27. - http://www.ji.lviv.ua/n27texts/kis.htm 
4. Маслова Ю. П. Моделі гендерної ідентичності жінки на сторінках друкованих змі [Електронний ресурс] / Ю. П. Маслова // Наукові праці Кам'янець-Подільського національного університету імені Івана Огієнка. Філологічні науки. - 2009. - Режим доступу до ресурсу: https://eprints.oa.edu.ua/1301/1/maslova1_120412.pdf.

5. Balczyńska-Kosman A. Udział kobiet w mediach a problematyka stereotypów płci [Електронний ресурс] / A. Balczyńska-Kosman // Wydział Nauk Politycznych i Dziennikarstwa UAM. - 2011. - Режим доступу до ресурсу: https://repozytorium.amu.edu.pl/bitstream/10593/6165/1/113-120.pdf.

6. Zatwarnicka-Madura B. Wizerunek kobiet w przekazach medialnych o charakterze informacyjnym [Електронний ресурс] / B. Zatwarnicka-Madura. - 2016. - Режим доступу до ресурсу: madura.b.pdffile:///C:/Users/user/Desktop/37 zatwarnicka-madura.b.pdf.

7. Маслова Ю. П. Особливості розвитку гендерних дінгвістичних досліджень в україні й закордоном [Електронний ресурс] / Ю. П. Маслова // Наукові записки Національного університету "Острозька академія". - 2015. - Режим доступу до pecypcy: $\quad$ http://www.irbis-nbuv.gov.ua/cgibin/irbis_nbuv/cgiirbis 64.exe?C21COM=2\&I21DBN=UJRN\&P21DBN=UJRN\&IMAGE FILE_DOWNLOAD=1\&Image file_name=PDF/Nznuoaf_2015_57_24.pdf.

8. Гендерні ролі та стереотипи [Електронний ресурс] - Режим доступу до pecypcy:

http://ekmair.ukma.edu.ua/bitstream/handle/123456789/4808/Oksamytna_Henderni_roli.p df.

9. Grabowska M. Stereotypy płci w reklamie w percepcji kobiet [Електронний pecypc] / M. Grabowska // Forum psychologiczne. - 2000. - Режим доступу до ресурсу: https://repozytorium.ukw.edu.pl/bitstream/handle/item/776/Grabowska\%20Stereotypy $\% 20$ plci $\% 20 \mathrm{w} \% 20$ reklamie $\% 20 \mathrm{w} \% 20$ percepcji $\% 20$ kobiet.pdf?sequence $=1 \&$ isAllowed $=\mathrm{y}$.

\section{References}

1. Oksamytna S. Genderni roli ta stereotypy [Elektronnyj resurs] / S. Oksamytna. - 2004. Rezhym dostupu do resursu: http://ekmair.ukma.edu.ua/bitstream/handle/123456789/4808/Oksamytna_Henderni_roli.p df.

2. Halustyan Yu. M. Deyaki aspekty hendernoyi identyfikaciyi ta socializaciyi osobystosti [Elektronnyj resurs] / Yu. M. Halustyan, V. P. Novyc"ka. - 2004. - Rezhym dostupu do resursu: https://ukr-socium.org.ua/wp-content/uploads/2004/01/7-13_no-1_vol3 _2004_UKR.pdf.

3. Kis" O. Modeli konstruyuvannya gendernoyi identychnosti zhinky v suchasnij Ukrayini / O. Kis" // Yi. - 2003. - № 27. - http://www.ji.lviv.ua/n27texts/kis.htm

4. Maslova Yu. P. Modeli hendernoyi identychnosti zhinky na storinkax drukovanyx zmi [Elektronnyj resurs] / Yu. P. Maslova // Naukovi praci Kam'yanec"-Podil"s"koho nacional"noho universytetu imeni Ivana Ohiyenka. Filolohichni nauky. - 2009. - Rezhym dostupu do resursu: https://eprints.oa.edu.ua/1301/1/maslova1_120412.pdf.

5. Balczyńska-Kosman A. Udział kobiet w mediach a problematyka stereotypów płci [Elektronnyj resurs] / A. Balczyńska-Kosman // Wydział Nauk Politycznych i 
Dziennikarstwa UAM. - 2011. - Rezhym dostupu do resursu: https://repozytorium.amu.edu.pl/bitstream/10593/6165/1/113-120.pdf.

6. Zatwarnicka-Madura B. Wizerunek kobiet w przekazach medialnych o charakterze informacyjnym [Elektronnyj resurs] / B. Zatwarnicka-Madura. - 2016. - Rezhym dostupu do resursu: file://C:/Users/user/Desktop/37_zatwarnickamadura.b.pdffile:///C:/Users/user/Desktop/37_zatwarnicka-madura.b.pdf.

7. Maslova Yu. P. Osoblyvosti rozvytku hendernyx dinhvistychnyx doslidzhen" v ukrayini j zakordonom [Elektronnyj resurs] / Yu. P. Maslova // Naukovi zapysky Nacional"noho universytetu "Ostroz"ka akademiya". - 2015. - Rezhym dostupu do resursu: http://www.irbis-nbuv.gov.ua/cgi-

bin/irbis_nbuv/cgiirbis_64.exe?C21COM=2\&I21DBN=UJRN\&P21DBN=UJRN\&IMAGE _FILE_DOWNLOAD=1\&Image_file_name=PDF/Nznuoaf_2015_57_24.pdf.

8. Henderni roli ta stereotypy [Elektronnyj resurs] - Rezhym dostupu do resursu: http://ekmair.ukma.edu.ua/bitstream/handle/123456789/4808/Oksamytna_Henderni_roli.p df.

9. Grabowska M. Stereotypy płci w reklamie w percepcji kobiet [Elektronnyj resurs] / M. Grabowska // Forum psychologiczne. - 2000. - Rezhym dostupu do resursu: https://repozytorium.ukw.edu.pl/bitstream/handle/item/776/Grabowska\%20Stereotypy\%20 plci $\% 20 \mathrm{w} \% 20$ reklamie $\% 20 \mathrm{w} \% 20$ percepcji $\% 20$ kobiet.pdf?sequence $=1 \&$ isAllowed $=\mathrm{y}$.

\section{Відомості про авторів:}

Ходачук Яна, Маслова Юлія

Національний університет «Острозька академія». 